\title{
Pengaruh Kreativitas Dosen Terhadap Prestasi Belajar Mahasiswa Pada Matakuliah Ekonomi Mikro Di Program Studi Perbankan Syariah Jurusan Syariah dan Ekonomi Islam STAIN Watampone
}

\author{
Zulkifli \\ Sekolah Tinggi Agama Islam Negeri Watampone, Bone, Indonesia \\ e-mail: nalling_jnp@ymail.com
}

\begin{abstract}
The purpose of this study is to find out how the influence of the creativity of lecturers in the learning process on student learning achievement in the Microeconomics Course in the Islamic Banking Study Program of the Sharia and Islamic Economics Department of STAIN Watampone. Data collection techniques used were questionnaires and documentation. The data analysis technique used is simple linear regression with the help of SPSS 20.00 software for Windows. Based on the results of the study show that the creativity of lecturers in the learning process has a positive and significant effect on student learning achievement in the Microeconomics Course in the Islamic Banking Study Program of the Shariah and Islamic Economics Department of STAIN Watampone.

Keywords: Creativity, learning achievement.
\end{abstract}

\section{Pendahuluan}

Pendidikan salah satu aspek yang sangat urgen dalam rangka membangun masa depan. Karena itu, pendidikan berperan mensosialisasikan kemampuan baru agar mampu mengantisipasi tuntutan masyarakat yang dinamik. ${ }^{1}$ Pendidikan adalah segala jenis pengalaman kehidupan yang mendorong timbulnya minat belajar untuk mengetahui dan mengerjakan sesuatu yang telah diketahui itu. Bahkan pendidikan berlangsung sepanjang zaman (life long education). Artinya sejak lahir sampai pada hari kematian seluruh kegiatan manusia adalah kegiatan pendidikan. $^{2}$

Pendidikan merupakan wahana yang tepat untuk mengembangkan kemampuan dan membentuk watak serta peradaban bangsa yang bermartabat dalam rangka mencerdaskan kehidupan bangsa serta mengarahkan manusia untuk hidup mandiri, kreatif, demokratis, bertanggung jawab, beriman dan bertaqwa kepada Allah SWT.

Undang-undang Sisdiknas nomor 20 Tahun 2003 mengamanatkan bahwa: "Pendidikan nasional berfungsi mengembangkan kemampuan dan membentuk watak serta peradaban bangsa yang bermartabat dalam rangka mencerdaskan

\footnotetext{
${ }^{1}$ Muhaimin, Konsep Pendidikan Islam (Solo: Ramadhan, 1991), h. 9.

${ }^{2}$ Anwar, Pendidikan Kecakapan Hidup (Bandung: Alfabeta, 2006), 43.
} 
kehidupan bangsa dan bertujuan untuk berkembangnya potensi peserta didik agar menjadi manusia yang beriman dan bertaqwa kepada Tuhan YME, berakhlak mulia, sehat, berilmu, cakap, kreatif, mandiri dan menjadi warga negara yang demokratis serta bertanggung jawab."3

Dalam proses pembelajaran di perguruan tinggi dosen adalah orang yang berwenang dan bertanggung jawab terhadap pendidikan mahasiswa. ${ }^{4}$ Seiring dengan tanggung jawab profesional pengajar dalam proses pembelajaran, maka dalam melaksanakan kegiatan pembelajaran setiap dosen dituntut untuk selalu menyiapkan segala sesuatu yang berhubungan dengan program pembelajaran yang akan berlangsung. Tujuannya adalah agar kegiatan pembelajaran dapat berjalan secara efektif dan efisien, yaitu tujuan akhir yang diharapkan dapat dikuasai oleh semua mahasiswa. ${ }^{5}$ Setiap dosen harus mengetahui tipe belajar mahamahasiswa agar kegiatan pembelajaran yang dilakukan dapat mencapai tujuan secara efektif dan efisien.

Dosen merupakan komponen yang menempati posisi sentral dan sangat strategis dalam sistem pendidikan, karena dosen terlibat langsung dalam proses belajar mengajar. Hanya dengan dosen yang kompeten, profesional dan memiliki kepribadian yang baik kegiatan belajar mengajar dapat berlangsung dengan lancar dan berkualitas. Mengingat begitu pentingnya posisi dosen dalam proses belajar mengajar sebagaimana telah disebutkan di atas maka apabila kualitas proses belajar mengajar mengalami penurunan atau kemunduran biasanya yang disalahkan hanya dosen dengan berbagai kelemahannya, yang dinilai kurang disiplin, kurang layak, kurang kreatif, dan lain sebagainya. ${ }^{6}$

Belajar mengajar adalah suatu kegiatan yang bernilai edukatif. Nilai edukatif mewarnai interaksi yang terjadi antara dosen dengan mahamahasiswa. Interaksi yang bernilai edukatif dikarenakan kegiatan belajar mengajar yang dilakukan, diarahkan untuk mencapai tujuan tertentu yang telah dirumuskan sebelum pengajaran dilakukan. dosen dengan sadar merencanakan kegiatan pengajarannya secara sistematis dengan memanfaatkan segala sesuatunya guna kepentingan pengajaran. ${ }^{7}$

${ }^{3}$ UU Sisdiknas No. 20 Tahun 2003, Tentang Sistem Pendidikan Nasional (Bandung: Fokus Media, 2006), 40.

${ }^{4}$ Syaiful Sagala, Kemampuan Profesional Dosen dan Tenaga Kependidikan (Bandung: Alfabeta, 2009), h. 21.

${ }^{5}$ Hamzah B. Uno \& Nurdin Muhamad, Belajar Dengan Pendekatan PAILKEM: Pembelajaran Aktif, Inovatif, Lingkungan, Kreatif, Efektif, Menarik (Jakarta: PT. Bumi Aksara, 2012), h. 3. 1999), h. 120.

${ }^{6}$ Fikri Gaffar, Perencanaan Pendidikan teori dan Metodologi (Jakarta: Dirjen Dikti,

${ }^{7}$ Syaiful Bahri Djamarah dan Aswan Zain, Strategi Belajar Mengajar (Jakarta: PT Rineka Cipta, 2013), h. 1. 
Keberhasilan pendidikan tergantung pada mutu pendidikan yang berkualitas serta dilaksanakanya dengan penuh tanggung jawab oleh seorang dosen. Dosen merupakan tenaga pengajar dalam menciptakan proses belajar mengajar yang dinamis, sehingga dapat menghasilkan mutu pendidikan yang berkualitas yang ditinjau dari segi pengetahuan maupun keterampilanya agar dapat mengembangkan potensi sesuai dengan sasaran dan tujuan dari pendidikan itu sendiri.

Melihat dalam proses pembelajaran saat ini motivasi belajar mahasiswa masih kurang nampak. Hal ini disebabkan kurangnya kreativitas dosen dalam proses pembelajaran. Di mana seorang dosen belum sepenuhnya bisa meningkatkan semangat (motivasi) belajar mahasiswa, sebab kreativitas dosen dalam hal aplikasi kompetensi-kompetensi dasar dalam mengajar masih belum maksimal terutama dalam hal pengelolaan kelas, penggunaan metode mengajar yang masih kurang, penggunaan media pembelajaran yang terbatas, teknik, ataupun pendekatan pembelajaran yang relevan antara kebutuhan mahasiswa dan materi pembelajaran yang disajikan.

Hal ini dapat dilihat dari adanya mahasiswa yang mengeluh tentang cara mengajar dosen yang kurang menarik, sehingga berakibat pada kurangnya motivasi mahasiswa dalam belajar. Secara singkat bahwa kemampuan dalam menciptakan sesuatu yang baru dalam hal proses pembelajaran belum maksimal. Sehingga hal tersebut menyebabkan kondisi belajar yang tidak dapat diikuti oleh tumbuhnya motivasi belajar dalam diri mahasiswa. Dengan demikian, kesadaran atau semangat (motivasi) mahasiswa untuk belajar masih kurang.

Kreativitas dosen sangat dibutuhkan dalam proses belajar mengajar untuk memotivasi mahasiswa selalu memperhatikan materi pelajaran yang diberikan dalam kegiatan pembelajaran sehingga memiliki prestasi belajar yang baik berbeda dengan mahasiswa yang tidak ada motivasi di dalam dirinya, maka motivasi ekstrinsik yang merupakan dorongan dari luar dirinya mutlak diperlukan. Di sini tugas dosen adalah membangkitkan motivasi peserta didik sehingga ia mau melakukan belajar. ${ }^{8}$

Perbankan Syariah nerupakan salah satu program studi yang ada di jurusan Syariah dan Ekonomi Islam pada STAIN Watampone, setiap dosen yang ada di program studi Perbankan Syariah diharapkan memiliki kreatifitas yang tinggi dalam proses belajar mengajar untuk meningkatkan prestasi mahasiswa. Salah satu matakuliah wajib yang ada di program studi Perbankan Syariah adalah

\footnotetext{
${ }^{8}$ Pupuh F dan Sobry Sutikno, Strategi Belajar Mengajar: melalui penanaman konsep umum dan konsep Islami (Bandung: PT Refika Aditama, 2009), h. 19-20.

${ }_{7}$ Hamzah B. Uno \& Nurdin Muhamad, Belajar Dengan Pendekatan PAILKEM: Pembelajaran Aktif, Inovatif, Lingkungan, Kreatif, Efektif, Menarik (Jakarta: PT. Bumi Aksara, 2012), h. 153.
} 
ekonomi mikro konvensional, untuk meningkatkan prestasi mahasiswa mengikiti kegiatan perkuliahan tersebut dibutuhkan kreativitas yang tinggi dari dosen yang bersangkutan.

Berdasarkan uraian-uraian diatas, maka tujuan dalam penelitian ini adalah untuk mengetahui pengaruh kreativitas dosen dalam proses pembelajaran terhadap prestasi belajar mahasiswa pada matakuliah ekonomi mikro di program studi perbankan syariah jurusan syariah dan ekonomi islam STAIN Watampone.

\section{Kretifitas}

Kreativitas adalah hasil belajar dalam kecakapan kognitif, sehingga untuk menjadi kreatif dapat dipelajari melalui proses belajar mengajar. ${ }^{9}$ Sedangkan Sedangkan Utami Munandar, menilai bahwa secara operasional kreativitas dapat dirumuskan sebagai hal yang mencerminkan kelancaran, keluwesan dan orisinalitas dalam berfikir, serta kemampuan untuk mengelaborasikan (mengembangkan, memperkaya dan memperinci suatu gagasan) ${ }^{10}$

Menurut Munandar bahwa kreativitas adalah kemampuan umum untuk menciptakan sesuatu yang baru, sebagai kemampuan untuk memberikan gagasangagasan baru yang dapat diterapkan dalam pemecahan masalah, atau sebagai kemampuan untuk melihat pengaruh baru antara unsur yang sudah ada sebelumnya. Kreativitas adalah kemampuan berdasarkan data atau informasi yang tersedia menemukan banyak kemungkinan jawaban terhadap satu masalah dimana penekananya adalah pada kuantitas ketepatgunaan dan keragaman jawaban. 11

Kreativitas yang dikutip dalam buku Ahmad Susanto, Yakni kreativitas adalah kemampuan seseorang untuk melahirkan sesuatu yang baru, baik berupa gagasan maupun karya nyata, yang relatif berbeda dengan apa yang telah ada sebelumnya. Sedangkan Dr. Syamsu Yusuf, I.N. Dr.A. Juntika mejelaskan bahwa yang dinamakan kreativitas itu adalah kemampuan untuk menciptakan produk yang baru atau kemampuan untuk memberikan gagasan baru dan menerapkannya dalam memecahkan masalah. ${ }^{12}$

Berdasarkan pendapat yang telah diuraikan diatas dapat disimpulkan bahwa kreativitas dosen dalam proses belajar mengajar adalah kemampuan yang mencerminkan kelancaran, keluwesan, dan orisinalitas dalam berfikir serta kemampuan untuk mengolaborasi suatu gagasan untuk menemukan cara-cara baru bagi pemecahan problema-problema dalam proses belajar mengajar.

\footnotetext{
${ }^{9}$ Slameto, Belajar Dan Faktor-Faktor Yang Mempengaruhinya (Jakarta: PT Rineka Cipta, 2010), hlm. 138 .

${ }^{10}$ Yatim Riyanto, Paradigma Baru Pendidikan (Jakarta: Kencana, 2010), hlm. 225.

${ }^{11}$ Munandar. Kreativitas dan keberbakatan startegi mewujudkan potensi kreatif dan bakat. (Jakarta : PT Gramedia pustaka Utama 2008) hlm.28

12 Syamsu, Yusuf Dan A. Juntika Nurishan, Landasan Bimbingan dan Konseling (Bandung: PT. Remaja Rosdakarya, 2006), h. 246
} 


\section{Indikator Kreativitas}

Kreativitas penting dimiliki bagi tenaga pengajar, untuk melihat berbagai kemungkinan penyelesaian terhadap suatu masalah dan dapat memotivasi peserta didik untuk belajar. Menurt Syaiful Bahri Yang menjadi indikator krativitas tenaga pengajar yaitu:

a). Penggunaan media pembelajaran yang menarik.

b). Penggunaan metode pembelajaran yang menarik

c). Mengembangkan strategi

d). Mampu menguasai kelas.

e). Gerakan anggota badan

f) Berpindah posisi saat mengajar

g) Variasi suara. ${ }^{13}$

Dengan adanya kreativitas tenaga pengajar tersebut dalam proses pembelajaran, maka diharapkan dapat mempengaruhi prestasi belajar peserta didik. Tenaga pengajar yang tidak kreatif dalam melaksanakan pembelajaran tentu akan membuat mahasiswa menjadi jenuh dalam mengikuti proses belajar, sehingga prestasi peserta didik menjadi rendah.

\section{Prestasi Belajar}

Menurut Dimyati dan Mudjiono, Pada umumnya Prestasi belajar meliputi ranah kognitif, afektif, dan psikomotorik". Berdasarkan pendapat di atas, dapat ditarik kesimpulan bahwa prestasi belajar adalah penilaian terhadap kemampuan peserta didik yang dinyatakan dengan skor yang dicapai dalam proses belajar mengajar yang diperoleh dari sistem tes yang dilakukan.

Prestasi belajar adalah kemampuan-kemampuan yang dimiliki mahasiswa setelah ia menerima pengalaman belajarnya. Horward Kingsley (dalam direktorat, 2008:46) membagi tiga macam hasil belajar, yakni: (a) keterampilan dan kebiasaan, (b) pengetahuan dan pengertian, (c) sikap dan cita-cita. Masingmasing jenis hasil belajar dapat diisi dengan bahan yang telah ditetapkan dalam kurikulum. Sedangkan Gagne membagi lima kategori belajar, yakni: (a) informasi verbal, (b) keterampilan intelektual, (c) strategi kognitif, (d) sikap, dan (e) keterampilan motoris.

Menurut Hamalik (2004:64) tingkah laku manusia terdiri dari sejumlah aspek. Hasil belajar akan tampak pada setiap perubahan pada aspek-aspek tersebut. Adapun aspek-aspek tersebut antara lain: (1) Kebiasaan, (2)

\footnotetext{
${ }^{13}$ Syaiful Bahri Jamarah, Dosen dan Anak Didik Dalam Interaktif Edukatif (Jakarta: PT. Rineka Cipta, 2000), h. 126-127.
} 
Keterampilan, (3) Apresiasi, (4) Emosional, (5) Hubungan sosial, (6) Jasmani, (7) Etis atau budi pekerti, dan (8) Sikap.

Prestasi belajar seringkali digunakan sebagai ukuran untuk mengetahui seberapa jauh seseorang menguasai bahan yang sudah diajarkan. Untuk mengaktualisasikan hasil belajar tersebut diperlukan serangkaian pengukuran menggunakan alat evaluasi yang baik dan memenuhi syarat. Pengukuran demikian dimungkinkan karena pengukuran merupakan kegiatan ilmiah yang dapat diterapkan pada berbagai bidang termasuk pendidikan (Purwanto, 2009).

Evaluasi hasil belajar adalah keseluruhan kegiatan pengukuran (pengumpulan data dan informasi), pengolahan, penafsiran dan pertimbangan untuk membuat keputusan tentang tingkat hasil belajar yang dicapai oleh mahasiswa setelah melakukan kegiatan belajar dalam upaya mencapai tujuan pembelajaran yang telah ditetapkan.Hasil belajar menunjuk pada prestasi belajar, sedangkan prestasi belajar itu merupakan indikator dan derajat perubahan tingkah laku mahasiswa (Hamalik, 2003).

Hasil belajar adalah kemampuan-kemampuan yang dimiliki mahasiswa setelah ia menerima pengalaman belajarnya. ${ }^{14}$ Hasil belajar merupakan perubahan-perubahan yang terjadi pada diri mahasiswa, baik yang menyangkut aspek kognitif, afektif, dan psikomotor sebagai hasil dari kegiatan belajar. Menurut Nawawi dalam K. Brahim, hasil belajar merupakan tingkat keberhasilan mahasiswa dalam mempelajari materi pelajaran yang dinyatakan dalam skor yang diperoleh dari hasil tes mengenal sejumlah materi pelajaran tertentu. ${ }^{15}$

Hasil belajar seringkali digunakan sebagai ukuran untuk mengetahui seberapa jauh seseorang menguasai bahan yang sudah diajarkan. Untuk mengaktualisasikan hasil belajar tersebut diperlukan serangkaian pengukuran menggunakan alat evaluasi yang baik dan memenuhi syarat. Pengukuran demikian dimungkinkan karena pengukuran merupakan kegiatan ilmiah yang dapat diterapkan pada berbagai bidang termasuk pendidikan. ${ }^{16}$

Setiap individu dalam melakukan suatu kegiatan selalu mengharapkan hasil yang dicapai secara maksimal. Dalam proses belajar mengajar, untuk mengetahui berhasil tidaknya seseorang dalam belajar sudah tentu memerlukan ukuran. Salah satu alat ukur yang digunakan adalah tes. Dengan mengukur hasil belajar, maka seseorang dapat mengetahui tingkat penguasaan materi yang diajarkan. Hasil belajar merupakan tolak ukur dalam dunia pendidikan, setelah menjalani proses

\footnotetext{
${ }^{14}$ Nana Sudjana, Penilaian Hasil Belajar Mengajar (Bandung: PT Remaja Rosdakarya, 2013), h. 22-23.. 2013), h. 5

${ }^{15}$ Ahmad Susanto, Teori Belajar Mengajar Di Sekolah Dasar (Jakarta: Kenacana,

${ }^{16}$ Ahmad Susanto, Teori Belajar...... ... 9
} 
pembelajaran maka peserta didik akan mendapatkan hasil belajar yang sesuai dengan apa telah dilakukannya. Hasil belajar tersebut dinyatakan berupa huruf dan angka mutu.

\section{Teknik Analisis Data}

Dalam penelitian ini, digunakan teknik analisis data yaitu:

1. Uji Normalitas,

Penggunaan uji normalitas karena pada analisis statistik parametik, asumsi yang harus dimiliki oleh data adalah bahwa data tersebut harus terdistribusi secara normal, maksudnya adalah bahwa data akan mengikuti bentuk distribusi normal. Uji normalitas bertujuan untuk menguji apakah dalam sebuah model regresi, variabel dependen dan variabel independen atau keduanya mempunyai dstribusi normal atau tidak. Jika data menyebar disekitar garis diagonal dan mengikuti arah garis diagonal maka model regresi memenuhi asumsi Normalitas.

\section{Uji Koefisien Regresi}

Uji koefisien regeresi di gunakan untuk mengetahui Pengaruh Kreativitas Dosen terhadap prestasi mahasiswa pada matakuliah ekonomi mikro di program studi perbankan syariah jurusan syariah dan ekonomi islam STAIN Watampone.

Model yang digunakan dalam penelitian ini adalah:

$$
\mathrm{Y}=\alpha_{+} \beta \mathrm{X}+\mathrm{e}
$$

Keterangan :

$$
\begin{aligned}
& \text { Y: } \quad \text { Prestasi Mahasiswa } \\
& \text { X: } \quad \text { Kreativitas Dosen dalam proses pembelajaran } \\
& \alpha: \text { Konstanta } \\
& \beta: \quad \text { Nilai Koefisien X1 dan X2 } \\
& \text { e : }
\end{aligned}
$$

\section{Kreativitas Dosen}

Berdasarkan hasil penelitian yang dilakukan dengan membagikan angket kepada mahasiswa program studi perbankan syariah yang telah mengikuti matakuliah ekonomi mikro, diperoleh hasil yaitu tingkat Kreativitas dosen mata kuliah ekonomi mikro, dikelompokan dalam lima kategori, yaitu: kategori tinggi, cukup, sedang, kurang dan rendah sebagai berikut: 
Gambar 1 Kategori Kreativitas dosen dalam proses pembelajaran

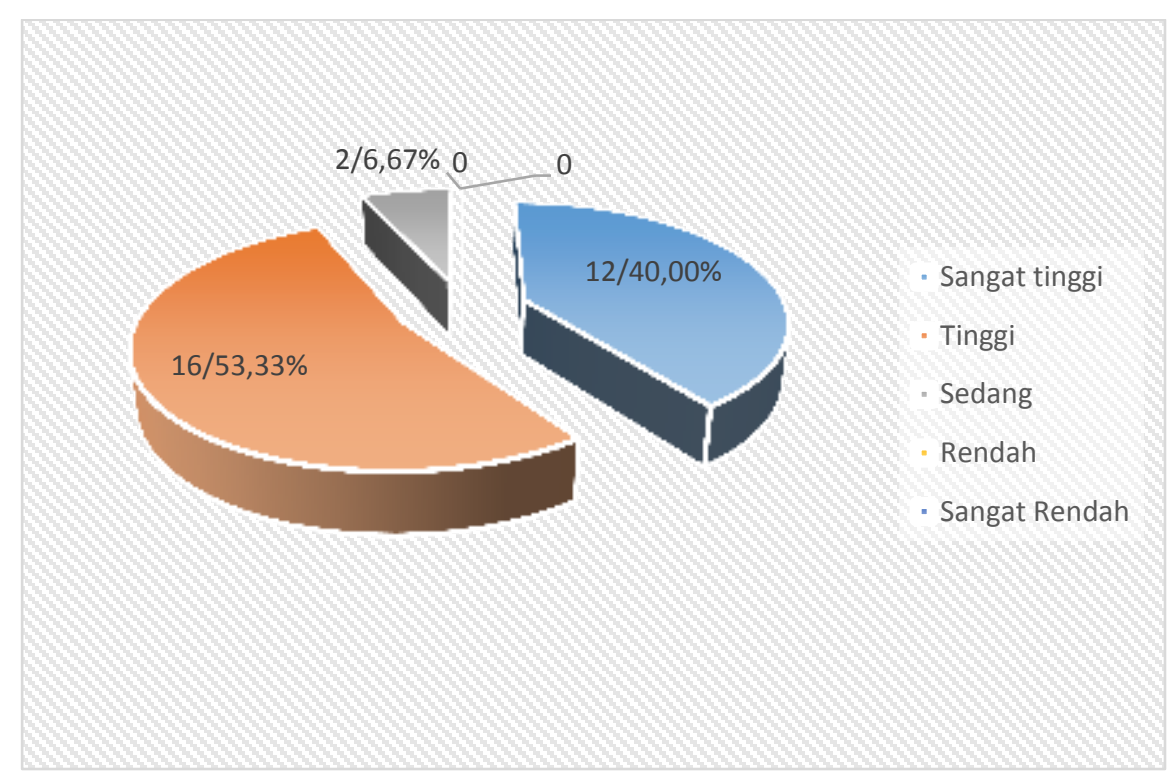

Sumber: Data hasil olah data 2017

Berdasarkan Gambar 1 diatas, diperoleh kreativitas dosen dalam kegiatan pembelajaran matakuliah ekonomi mikro yaitu mahasiswa yang menjawab dosen memiliki Kreativitas sangat tinggi yaitu sebanyak 12 mahasiswa atau 40,00\% dari total responden, mahasiswa yang menjawab dosen memiliki Kreativitas tinggi yaitu sebanyak 16 mahasiswa atau 63,33\% dari total responden, mahasiswa yang menjawab dosen memiliki Kreativitas sedang yaitu sebanyak 2 siswa atau 6,67\% dari total responden, dan tidak ada mahasiswa yang menjawab dosen memiliki Kreativitas rendah dan sangat rendah.

\section{Prestasi Mahasiswa}

Proses belajar mengajar di kelas mempunyai tujuan yang bersifat transaksional, artinya diketahui secara jelas dan operasional oleh dosen dan mahasiswa. Tujuan tercapai jika siswa memperoleh hasil belajar seperti yang diharapkan di dalam proses belajar mengajar tersebut. Oleh sebab itu, hasil belajar harus dirumuskan dengan baik untuk dapat dievaluasi pada akhir pembelajaran.

Berdasarkan hasil penelitian diperoleh hasil belajar matakuliah ekonomi mikro pada program studi perbankan syariah jurusan syariah dan ekonomi islam STAIN Watampone yaitu: hasil belajar mata kuliah ekonomi mikro, dilakukan pengelompokan dalam lima kategori, yaitu : kategori tinggi, cukup, sedang, kurang dan rendah. Berdasarkan hasil penelitian diperoleh hasil belajar mahasiswa sebagai berikut: 
Gambar 2 Kategori prestasi belajar mata kuliah ekonomi mikro

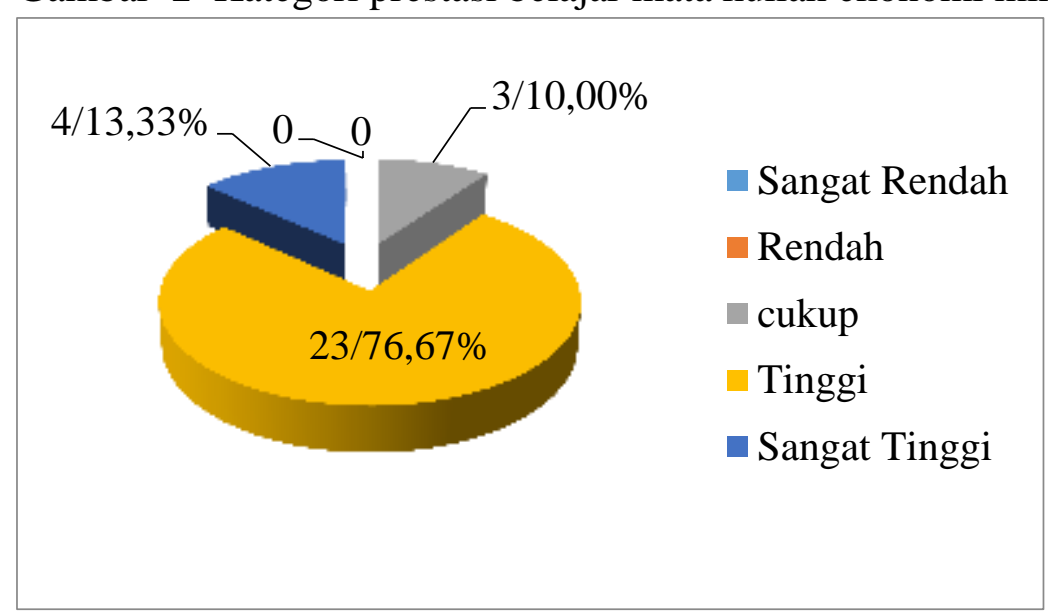

Sumber: Data hasil olah data 2017

Berdasarkan Gambar 2 diatas, diperoleh hasil belajar mata kuliah ekonomi mikro yaitu mahasiswa yang memiliki hasil belajar sangat tinggi yaitu sebanyak 4 mahasiswa atau 13,33\% dari total responden, mahasiswa yang memiliki hasil belajar tinggi yaitu sebanyak 23 mahasiswa atau 76,67\% dari total responden, mahasiswa yang memiliki hasil belajar sedang yaitu sebanyak 3 mahasiswa atau $10,00 \%$ dari total responden, dan tidak ada mahasiswa dengan hasil belajar rendah dan sangat rendah,

\section{Pengaruh kreativitas dosen terhadap prestasi mahasiswa pada matakuliah ekonomi mikro di program studi perbankan syariah jurusan syariah dan ekonomi islam STAIN Watampone}

\section{a. Uji Normalitas}

Berdasarkan hasil olah data dapat dilihat bahwa titik-titik menyebar disekitar garis dan mengikuti garis diagonal, sehingga dapat disimpulkan bahwa data yang digunakan dalam penelitian ini adalah berditribusi normal sehingga dapat dilanjutkan pada analisis regresi.

Gambar 3 Scotter Plot Uji Normalitas Data

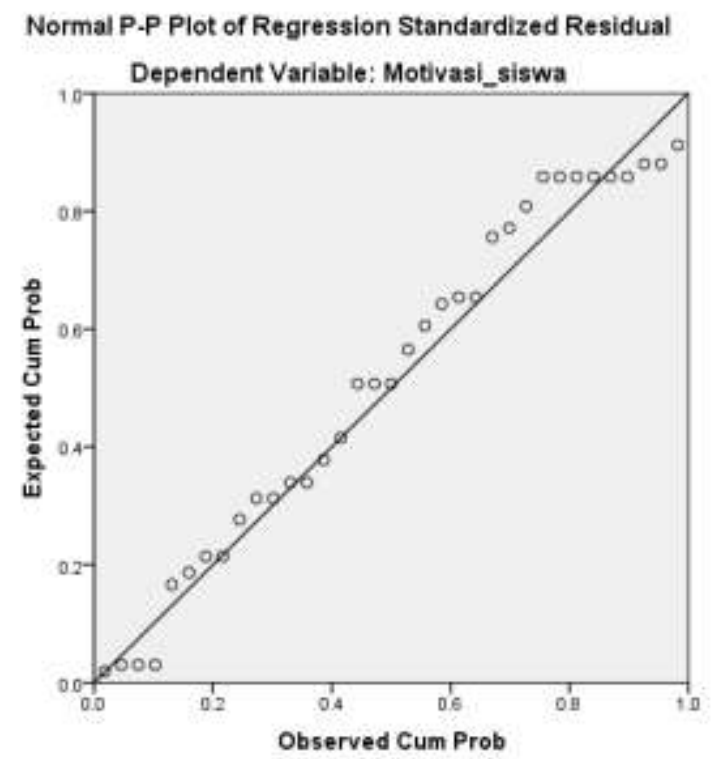




\section{b. Uji regresi linear sederhana}

Analisis regresi linear sederhana digunakan untuk mengetahui seberapa besar pengaruh variabel bebas terhadap varibel terikat. Analisis regresi linear sederhana dalam penelitian ini menggunakan program SPSS versi 20 yang dapat dilihat pada tabel 4.30 sebagai berikut:

Tabel. 3 Hasil Olah Data Regresi Linear Sederhana

Coefficients $^{\mathrm{a}}$

\begin{tabular}{|c|c|c|c|c|c|}
\hline \multirow[t]{2}{*}{ Model } & \multicolumn{2}{|c|}{$\begin{array}{l}\text { Unstandardized } \\
\text { Coefficients }\end{array}$} & \multirow{2}{*}{\begin{tabular}{|c|}
$\begin{array}{c}\text { Standardize } \\
\mathrm{d} \\
\text { Coefficients }\end{array}$ \\
Beta \\
\end{tabular}} & \multirow[t]{2}{*}{$\mathrm{T}$} & \multirow[t]{2}{*}{ Sig. } \\
\hline & $\bar{B}$ & Std. Error & & & \\
\hline (Constant) & 1.120 & .523 & & 1.326 & .021 \\
\hline $\begin{array}{l}1 \text { Kreativitas_d } \\
\text { osen }\end{array}$ & .617. & .731 & .824 & 3.842 & .000 \\
\hline
\end{tabular}

a. Dependent Variable: Prestasi_mahasiswa

Berdasarkan hasil olah data tersebut persamaan dalam penelitian ini menjadi:

$Y=1.120+0.617+\varepsilon$

1) Nilai costanta sebesar 1.120

Jika tidak ada perubahan pada nilai variabel kreativitas dosen maka prestasi belajar mahasiswa sebesar 1.120

2) Nilai koefisien regresi kreativitas dosen sebesar 0,617

Nilai koefisien regresi kreativitas guru sebesar 0,617 menunjukkan bahwa jika kreativitas dosen dalam pembelajaran naik sebesar 1 maka prestasi belajar mahasiswa akan naik sebesar 0,617. Dan sebaliknya kreativitas dosen turun sebesar 1 maka prestasi belajar mahasiswa akan turun sebesar 0,617. Sehingga dapat disimpulkan kreativitas dosen berpengaruh positif terhadap prestasi belajar mahasiswa pada matakuliah ekonomi mikro.

3) Nilai signifikansi sebesar 0,000

Nilai signifikansi sebesar 0,000 menunjukkan bahwa variabel kreativitas dosen dalam pembelajaran matakuliah ekonomi mikro berpengaruh signifikan terhadap prestasi belajar mahasiswa di Program studi perbankan syariah jurusan syariah dan ekonomi islam STAIN Watampone.

\section{Simpulan}

Berdasarkan hasil penelitian maka dapat disimpulkan bahwa kreativitas dosen dalam pembelajaran matakuliah ekonomi mikro berpengaruh positif dan signifikan terhadap prestasi belajar mahasiswa di Program studi perbankan syariah jurusan syariah dan ekonomi islam STAIN Watampone. 


\section{Daftar Pustaka}

Anwar, 2006. Pendidikan Kecakapan Hidup Bandung: Alfabeta

Fikri Gaffar,1999. Perencanaan Pendidikan teori dan Metodologi. Jakarta: Dirjen Dikti, 1999.

Hamzah B. Uno \& Nurdin Muhamad, 2012. Belajar Dengan Pendekatan PAILKEM: Pembelajaran Aktif, Inovatif, Lingkungan, Kreatif, Efektif, Menarik Jakarta: PT. Bumi Aksara.

Muhaimin, 1991. Konsep Pendidikan Islam Solo: Ramadhan.

Munandar, 2008. Kreativitas dan keberbakatan startegi mewujudkan potensi kreatif dan bakat. Jakarta : PT Gramedia pustaka Utama.

Pupuh F dan Sobry Sutikno, 2009. Strategi Belajar Mengajar: melalui penanaman konsep umum dan konsep Islami Bandung: PT Refika Aditama.

Syamsu, Yusuf dan A. Juntika Nurishan. 2006 Landasan Bimbingan dan Konseling Bandung: PT. Remaja Rosdakarya

Syaiful Bahri Djamarah, 2000 Dosen dan Anak Didik Dalam Interaktif Edukatif Jakarta: PT. Rineka Cipta

Syaiful Bahri Djamarah dan Aswan Zain,2013. Strategi Belajar Mengajar Jakarta: PT Rineka Cipta.

Slameto, 2010. Belajar Dan Faktor-Faktor Yang Mempengaruhinya Jakarta: PT Rineka Cipta.

Syaiful Sagala, 2009. Kemampuan Profesional Dosen dan Tenaga Kependidikan Bandung: Alfabeta.

UU Sisdiknas No. 20 Tahun 2003, Tentang Sistem Pendidikan Nasional Bandung: Fokus Media.

Yatim Riyanto,2010. Paradigma Baru Pendidikan Jakarta: Kencana, 2010. 